\title{
Environmental Politics in the Himalayas: A Retrospective Overview of People's Resistance to Protect their Rights Over Natural Resources
}

\author{
Narayan Jena ${ }^{1}$ and Swagatika Parida $^{2}$ \\ ${ }^{1}$ Department of English and Foreign Languages, ${ }^{2}$ Department of Business Administration \\ ${ }^{1 \& 2}$ SRM University, Chennai, Tamil Nadu, India \\ E-Mail: jnarayan83@gmail.com, swagatikaswt@gmail.com
}

\begin{abstract}
This paper attempts to examine the fundamental reasons behind the constant battle of the local people of Uttarakhand over the Himalayan resources since the colonial time. It analyses both the social effects of the deliberate shifting of ownership of natural resources from the local people to government agencies and the ecological impact of dramatic conversion of natural forest into protected areas or reserve forests. Secondly, it questions the validity of such structural changes made by the governments to limit or restrict the local people's access to the resources of the region. Here, the primary materials for this paper have been derived from the responses of the local people on the government's shifting and developmental paradigm to substantiate the argument.
\end{abstract}

Keywords: Himalayan Resources, Environment Movement, Civil Right, Resistance

\section{INTRODUCTION}

The history of human ecology in the Himalayas is unlike any fairy tales or romantic narratives, in which life is projected as beautiful and satisfying in the midst of bucolic landscape or idyllic countryside. The mountain life has never been easy, rather people undergo constant struggle to fulfil their subsistence need, to claim their rights over the natural resources (as the basis of their life), to justify the appropriateness of their practices with respect to the mountain ecology, to retain their historical identity as a part of their ecological identity. They fight legal and political battles against the administration of the state by demeaning it as anarchic, anti people and ecologically destructive as the developmental activities enforced by the government have never gone in compliance with the eco-ethical development and people's democratic right. It has been observed that in the recent past many laws and local welfare plans have been framed, yet they are viewed as antithetical to what is actually required by the people. And they loom to be unacceptable by the local as the later are apprehensive of the new rules which may further intensify their deprivation of subsistence and development. It is evident that when a rule or an action (pertinent to the rule) is new in an existing system and does not go in consonance with the system, there arises conflict and resistance (Karnik, 2005). Implementation of new rules and their alteration under the rule of many kings and conquerors in the Himalayan region could not be accepted by local people (Dittmer, 2005). Especially the colonial laws for the formulation of 'protected forest' or 'reserved areas'- with an intension to show managerial approach to the forest use for their uninterrupted economic benefit through the use of resources for a longer period of time- appeared antagonistic to the conventional method of resource utilization by the local people (Neggi, 1998; Rangarajan, 2003). As people became aware of the adverse effects of colonial laws, the whole $20^{\text {th }}$ century turned out to be full of movements, debates, resistance etc. And the present days movements are the reiteration of the resistance since the British colonial time as the laws are viewed to be the replication of the colonial rules.

\section{REVIEW OF LITERATURE}

In last few decades, environmentalism has become a global discourse in academics and political institutions. At local and social level people have shown their concern for the protection of natural resources. Ramchandra Guha (2000) observes that such concern for environment is compounded with concern for social justice as the environmental policies at different point in history have estranged the local people from their eco-cultural roots. So environmentalism in India foregrounds on 'nature-based conflicts, which have originated from "lopsided, iniquitous, and environmentally destructive process of development in independence India" (Guha and Martinez-Alier, 1997, p. 17). The aim is to protest against the destructive, anti-people and elite-centric developmental approach of the state, in which the rights of people are discarded and their voices are tried to be repressed, and focus is shifted from people to urban growth. Rout (2009) observes that the environmental movements in India are the struggles over "the process of production and extraction" (p. 327). Similarly, Amita Baviskar (1995) has viewed such movements as contests between 'political economy of profit' and 'moral economy of needs'.

Again, a very strong social basis of the environmental movements has been viewed by Tong (2005) as he says "Environmental movement is a type of social movement that involves an array of persons, groups and coalitions that observe a common interest in environmental protection and act to bring about changes in environmental policies and practices" (p. 68). Similarly, Gadgil and Guha (1995) have viewed the environmental movements as "organized social activity consciously directed towards promoting sustainable 
use of natural resources halting environmental degradation or bringing about environmental restoration" (p. 98). And according to Rootes (1999), "The environmental movements are conceived as broad networks of people and organizations engaged in collective action in the pursuit of environmental benefits" (p. 2). The local movements of the inhabitants and common mass, who are aggrieved by the effects of environmental degradation, de-legitimization of people's right of access to local resources and the conversion of ownership of land, with having close affinity to civil right movements get support from political institutions, non-profit organizations, individuals, educated mass etc.. Siva (1988) has underlined the importance of the involvement of women in the direct activities of ecosystem people; and Gadgil and Guha (1995) have focused on the role of middle class intellectuals to disseminate the ideas of environmental movements to protect the rights of local people over the resources. Here it may be mentioned that the existing literature talks about the nature and scope of environmental movements in India and the world. And the present paper will examine how historically such movement got momentum and proliferation in the Himalayan region and how far they have thrived to protect the people's right over nature in the Himalayas.

\section{RESEARCH METHODOLOGY}

This work is partially theoretical and partly ethnographic. Here, we have taken historical approach, and for later (Ethnographic study) we travelled in the Himalayan region for few months to gather necessary information related to people's emotional, and socio- economic relationship with the mountain, through participatory observation and interaction with the local folks. In the course of this study, we had interviewed more than 200 people including farmers, business men, journalists, activists, academicians, students and local non-government organizations to deduce the real political condition of the region and the local people's role in the environmental politics.

\section{RESULTS AND DISCUSSION}

In 1916, villagers from Kumaon and Garhwal regions started resisting against colonial rules for unpaid coolie labours. As a part of that rule the villagers were forced to work for the master without any remuneration. The demand for such labourer increased during the World War I and thousands of local people were forced to get the title as "recruitment for the colonial army, coupled with expanded labour demands to meet the war time timber needs" and increasing labour need in the commercial agriculture sector, brought an acute shortage of labourers (Tucker, 1982, p. 118). But the labourers were thoroughly denied their civil rights and privileges. Being deprived of the right to sustainable living condition while working for colonial master was understood as the seer violation of human right. Consequently it leads to a massive uprising of labour community, which were termed as "coolie beggar movements". And such 'movements' were directed against the Revenue and Forest Department under the European administration and the private employers. So this movement turned out to be massive social movements. Getting support from all directions and being politically motivated by the local and national intellectuals, townsmen, nationalist movement leaders etc. the movements resulted in a temporary respite of people from the persecution of unpaid labour law.

After considerable victory of the mass in 1921, there was a massive movement in Garhwal in 1930, along with the national movements, known as Tilahdi Movement. This movement gained ground against the government and forest laws with a comprehension that such rules separate the people from their nature base; and it was understood that separating people from their land was a colonial method to subdue the customary ownership of local people over the resources (Tucker, 1984). People showed their contempt against Revenue Department's act of collecting taxes from the local people for staying in the forest areas and using it for agriculture, fodder etc. It is reported that, this is for the first time people articulated not only their right over the resources but also their deep seated relation with the mountain. Similar approach continued in 1942 Almora Movement. The idea that triggered the movement came out of a fundamental question "when people have access to the land since time immemorial, why will tax be paid to the colonial administration and why permission would be sought to use it for agriculture or animal rearing etc.?"

Again, with growing awareness among the local people about the importance of the mountain in their socio-cultural life, gradually developed a sense of responsibility among the people for its resources. Their concern for this land made them to fight against incessant exploitation either by Government or by the capitalists in collaboration with the government agencies. Along with their realisation that massive exploitation of mountain resources not only damages its ecology and geophysical sensitivity, but also undermines the basis of their life the local people gradually gained deep understanding of the fact that the Himalayas is not a mere geographical location in India, but a highly sensitive zone that influences the geophysical system in global level, and that needs to be preserved with utmost care (Dewan, 1990). They felt that the model enforced by the government (colonial as well as Indian government) either for development or for resource conservation and management were not locally appropriate as they are the extension and continuation of European exploitation. So, in 1960, there was a movement in the Himalayan region of Uttarakhand, Himachal Pradesh etc. known as "save Himalaya movement". It is for the first time people showed their intellectual orientation towards the protection of the mountain.

Many intellectuals of the region started analysing various issues related to its ecological degradation. Most of them attributed the alienation of local people from the place as the foremost reason of the mountain degradation; and they 
underlined the inalienable relation between the region and people. They regarded the mountain and its resources as the properties of local community, for which the local leaders like Rishiballav Sundaiyal suggested that the Himalayas could be preserved in the hands of local people and no law separating the local people from the forest could be successful in preserving it. So in 1962, attention was deliberately given on socio-economic-cultural condition of local people along with the idea of protecting the land as social life was felt to be directly connected to the environment.

As already indicated, during British raj the devastation of Himalayan forest reached the climax. New methods were introduced for the management of Indian forests and new policies for the transfer of ownership of the forest land, which was to make the condition favourable for the government to use the resources to the maximum and in their own way. The consequence of such management is studied by Kusum Karnik; as she observes, "Gharwal and Kumaun hill areas, which were heavily forested, bore the brunt of British scientific forestry, which was just commercial forestry, replacing natural forest by commercial, exotic monocultural plantations. This deforestation brought in changes by eroding the basis of subsistence agriculture, large scale outward migration, creation of a money order economy- leading to a total collapse" (Karnik, 2005, p. 30). The devastation of traditional forest brought an end to conventional local practices, which further led to deterioration of socioeconomic condition of local folk. And Chipko Movement took its origin from local people's concern for the protection of the land and protection of their right over the land. This was a form of resistance against the Indian government's policy, which was the continuation of "colonial ways" with "increasing proportion" (Karnik, 2005, p.31). This movement was evidently against facilitation of commercial forestry and political appropriation of resource use by commercial enterprises.

People demanded restoration of their right over the forest with a strong argument that the forest belonged to the local community because they have nurtured it to grow, protected it from many mishaps and their life depends on its resources (Karnik, 2005, p. 32). To resist logging of forests people clung to the trees and did not allow the contractors to touch them. This non-violent resistance is symbolic of their physical association with the forest and the death of which is the end of their life. As a matter of fact in the year 1973, in Reni, near Joshimath, women in massive number took part in Chipko movement. As a result of vehement opposition, the whole tract of Neethi- (Reni is a part of this large tract) was declared as reserve forest. But it is a political irony that in this reserved area the hills and slopes are gradually denuded and the tract has become victim of the machination of development. Again in 1974, students and youth participated in the movement, which significantly contributed to the Chipko. In 1977, youth mass urged the government not to renew the contract of clearing forest and
Kumaon Van Bachao Sangharsh samiti opposed the government's attempt to sell forest. In 1978, local people near Dwarhat fought against the contractors and their labourers; that is widely known as Chanchidhar Movement.

Although such movements were intended to protect 'local people's right over natural resources' the political motif of such movement is not confined within it. Their sense of right is backed by the idea that their individual or community life is deeply implicated in the local ecological system. These people's living in these areas and dependency on the ecosystem over centuries have made them to develop concrete knowledge about the system; and their cultural practices clearly indicate their love, faith and knowledge of the bio- regions of the mountain. It is informed to us during the time of our interaction with local people that most of the wilder areas in the Himalayas are consecrated to local deities and no human encroachment is allowed to those places before a particular period in a year.

By such practice they allow the wildlife to survive, procreate and flourish without any human induced disturbance and they are subsequently of larger help to the local community. It does not mean that the idea of protection is backed by narrow intension of individual benefit, but indicates their concern and correlation with the land, and the benefit mutually comes from such relation. Karnik, indicating people's conventional attitude towards Himalayan resources in Pre-British India, mentions: "people had near-total control over their forest, showed deep love of vegetation and felt a sense of responsibility towards future generations. The community was homogeneous and democratic in nature, and acted as a community taking care of their natural common property resources" (Karnik, 2005, p. 29).

In the present time there is a growing awareness of scientific and cultural necessity of the environment among the people. They gradually understand the fact that over exploitation of resources by the "favoured few" not only affects local livelihood (Tucker, 1982, p. 114), and their relation with the environment, but also disturbs the climatic conditions, air, aquatic system, rain cycle, land productivity, biological diversity, mountain sustainability, immunity system etc. not in the local level but at the level of the planet. They have a clear comprehension of the fact that the increasing number of natural calamities like changing of river course, land slide, earth quake, flood etc. in the recent years is due to mountainous pressure of developmental work on the young mountain.

The local intellectuals have developed sound empirical knowledge of the geo-merphology and bio-physical nature of the mountain, by which they analyse various critical issues related to the environment and life and their prospective solutions. They also understand that the local environmental problem is not an "isolated" event or phenomena, but associated with many factors- from human to mechanical. Here it may be mentioned, if the movements 
in the Himalayan region are backed by such ideas, they may be regarded as more environmental than social, in which people's attempt to protect nature comes prior to their fighting for owning resources.

In the wake of Chipko, the Government, in the name of absolute safety of the local forests, declared the areas as the protected zones. As a result the access in to the areas was prohibited or restricted. It is evident that the bureaucratic intervention not only shattered the livelihood of local folks, but also tried to rationalise the separation of people from nature. In the pre-Chipko period, the government tried to decimate the local forest in the name of industrial or economic development. After Chipko, the government restricted the zone, by enforcing stringent laws, by which the area came under direct control of the state forest department. To get access in to the area required complicated legal procedure, which appeared to be impossible task for the local people. And the 1980 forest act appeared to be more stringent than ever. As a part of the regulation local people's entry in to the protected areas was completely restricted.

Thus, it restricted their act of cultivation as large chunk of their cultivable land was located within the boundary of the national parks, practice of collection of fodder, fuel, weeds and plants and many other forest products, which their socio-economic life subsists on. For instance, declaration of "Nandadevi National park" took away right of living of more than 1500 people of about 12 villages near the park. Even certain villages inside the protected area are denied of getting access to the land. Some seven villages in the vicinity of Binsar sanctuary are still victims of such forest law; and at the same time private agencies are allowed to make trade of land there.

It appears to be a political gimmick to favour the capitalist mass by depriving the local poor. As reaction to such ambivalent forest law people started Jhapto Chino movement, in which they claimed their right over local forest by force. As a challenge to state administration, people under the leadership of Govind Singh Rawat, entered the national parks secretly and by force. That was to prove their age old association and familiarity with the region and forest department's least knowledge about it. Villagers from Reni, Laata, Muranda, Peing, Tolma and others collected firewood, herbs, fodder etc. from the national park by force. Again, thousands of acres of forest land were blazed by the people out of anger and contempt for the law.

During that time when people were fighting for the protection of forest in the Himalayan tract, the government's attempt to build high dams and power projects was severely opposed by the local folks. They reached the level of understanding that if the large projects ware not curbed it would be impossible to save the sensitive valleys like Kedar valley, Valley of Flowers, Rudraprayag, Nethee, Alakananda Valley, Bhagirathi valley, Bhilangana valley etc. As a consequence at the worst, thousands of acres of arable land would be submerged. So Anti-dam movement as an extension of Chipko was perhaps grounded for the protection of jal, Jungle, Jameen (water, forest, Land) from further exploitation.

\section{FINDINGS OF THE STUDY}

In this connection, it is explicit that both government and people attempt to save the mountain environment, yet the method undertaken by the government is opposed by people. Evidently, the government's methods have been complete failure and have shown disastrous result in protecting the natural areas. Secondly, its anti-local and prodevelopmental approach is considered as wrong turn and ecologically and economically destructive. Thirdly, through the enforcement of law, community right over the land is shattered, and areas are labelled as government's property, which turns to be detrimental for socio-economic life of local community. So the people do not fight against any alien force or its rules, rather fight against their own government.

It has been claimed that the natural resources are secured with the local community, so the destiny of the forest may be left to them. But this idea is rejected by state forest department with a view that large patches of forest land are being decimated and local biodiversity is being destroyed, wild animals are being killed, precious, exotic plants and herbs are being taken away, trees are being cut, mountain slopes are being denuded etc. by local people. Without resisting their entrance into protected areas it is hardly possible to save the mountain valleys and forests. It is clear that the views of local people and that of the government agencies are visibly discordant to one another. So the protection of the mountain environment appears to be an impossible task.

\section{CONCLUSION}

From such constant battle, resistance and discourses the question arises who should have the actual ownership of the forest land of the mountain tracts? How should the ownership be determined and would be justified in the philosophy of ecological politics? Is it possible to protect natural resources and the land by dissociating or dislocating local people from the land by law? How far is it possible to monitor the resource use without the interference of potential law? And how far the conventional, cultural methods are appropriate and effective in restraining the resource use at the present time when people are in a rat race of profit making business? etc. It may be mentioned that in a democratic system of India there is the need of certain prospective rules to be implemented to bring about utopian condition of socio-economic and environmental harmony as well as to re-establish and reinforce people's relation with their places, by which the newly emerging issues of migration of local people, marginalization of places, stigmatization of local practices will perhaps be brought to an end. 


\section{REFERENCES}

[1] Baviskar, A. (1995). In the Belly of the River: Tribal Conflicts over Development in the Narmada Valley. New Delhi, India: Oxford University.

[2] Dewan, M. L. (1990). Ecological Havoc in the Himalayas and its Reedies. In S.K. Chadha (Ed.), Himalayas: Environmental Problems 1-14.NewDelhi, India: Ashis Publishing House.

[3] Dittmer, L. (2005). Power politics in the Himalaya and Beyond: Introduction. Asian Survey, 45(4), 497-502.

[4] Gadgil, M., \& Guha, R. (1995). Ecology and Equity: Use and Abuse of Nature. Harmondsworth, England: Penguin Books.

[5] Guha, R. (2000). Environmentalism: A Global History. New Delhi, India: Oxford University Press.

[6] Guha, R., \& Martinez-Alier, J. 1997. Varieties of Environmentalism: North and South. New Delhi, India: Oxford University Press.

[7] Karnik, K. (2004). People's movements for Natural Resources. In S.N. Power (Eds.), Environmental Movements in India: Strategies and Practices. 27-35. New Delhi, India: Rawat Publications.

[8] Neggi, S. S. (1998). Discovering the Himalaya. ( $1^{\text {st }}$ ed.) 2, New Delhi, India: Indus Publishing Company.
[9] Rangarajan, M. (2003). The Politics of Ecology: The Debate on Wildlife and people in India, 1972-95. In V. K Sabarwal \& M Rangarajan (Eds.), Battle over Nature: Science and Politics of Conservation.189-239. New Delhi, India: Orient Longman.

[10] Rangarajan, M. (2003). State, Communities and Conservation: The practice of Eco development in Great Himalayan National Park. In V. K Sabarwal

\& M. Rangarajan (Eds.), Battle over Nature: Science and Politics of Conservation. 267-299. New Delhi, India: Orient Longman.

[11] Rootes, C. (1999). Environmental Movements: From the Local to the Global. Environmental Politics, 8(1), 1-12.

[12] Shiva,V.(1988). Staying Alive: Women, Ecology and Survival in India. New Delhi, India: Kali for Women.

[13] Tong, Y. (2005). Environmental Movements in Transitional Societies: A Comparative Study of Taiwan and China. Comparative Politics, 37(2), 167-188.

[14] Tucker, R. P. (1982). The Forests of the Western Himalayas: The Legacy of British Colonial Administration. Journal of Forest History, 26(3), 112-123.

[15] Tucker, R. P. (1984). The Historical Context of Social Forestry in the Kumaon Himalayas. The Journal of Developing Areas, 18(3), 341356. 